\title{
Roscoe Reid Graham (1890 to 1948): a Canadian pioneer in general surgery.
}

\author{
Christine C. Piper, BA \\ Thomas Jefferson University \\ Charles J. Yeo, MD \\ Thomas Jefferson University \\ Scott W. Cowan, MD \\ Thomas Jefferson University
}

Follow this and additional works at: https://jdc.jefferson.edu/gibbonsocietyprofiles

Part of the History of Science, Technology, and Medicine Commons, and the Surgery Commons Let us know how access to this document benefits you

\section{Recommended Citation}

Piper, BA, Christine C.; Yeo, MD, Charles J.; and Cowan, MD, Scott W., "Roscoe Reid Graham (1890 to 1948): a Canadian pioneer in general surgery." (2014). Department of Surgery Gibbon Society Historical Profiles. Paper 23.

https://jdc.jefferson.edu/gibbonsocietyprofiles/23

This Article is brought to you for free and open access by the Jefferson Digital Commons. The Jefferson Digital Commons is a service of Thomas Jefferson University's Center for Teaching and Learning (CTL). The Commons is a showcase for Jefferson books and journals, peer-reviewed scholarly publications, unique historical collections from the University archives, and teaching tools. The Jefferson Digital Commons allows researchers and interested readers anywhere in the world to learn about and keep up to date with Jefferson scholarship. This article has been accepted for inclusion in Department of Surgery Gibbon Society Historical Profiles by an authorized administrator of the Jefferson Digital Commons. For more information, please contact: JeffersonDigitalCommons@jefferson.edu. 


\title{
Roscoe Reid Graham (1890 to 1948): A Canadian Pioneer in General Surgery
}

CHRISTINE C. PIPER, B.A., CHARLES J. YEO, M.D., SCOTT W. COWAN, M.D.

\author{
From the Department of Surgery, Thomas Jefferson University, Jefferson Medical College, \\ Philadelphia, Pennsylvania
}

\begin{abstract}
Roscoe Reid Graham, a Canadian surgeon trained at the University of Toronto, was a true pioneer in the field of general surgery. Although he may be best known for his omental patch repair of perforated duodenal ulcers-often referred to as the "Graham patch" - he had a number of other significant accomplishments that decorated his surgical career. Dr. Graham is credited with being the first surgeon to successfully enucleate an insulinoma. He ventured to do an essentially brand new operation based solely on his patient's symptoms and physical findings, a courageous move that even some of the most talented surgeons would shy away from. He also spent a large portion of his career dedicated to the study of rectal prolapse, working tirelessly to rid his patients of this awful affliction. He was recognized by a number of different surgical associations for his operative successes and was awarded membership to those both in Canada and the United States. Despite all of these accolades, Dr. Graham remained grounded and always fervent in his dedication to the patient and their presenting symptom(s), reminding us that to do anything more would be "meddlesome." In an age when medical professionals are often all too eager to make unnecessary interventions, it is imperative that we look back at our predecessors such as Roscoe Reid Graham, for they will continually redirect us toward our one and only obligation: the patient.
\end{abstract}

$\mathrm{R}$ OSCOE REID GRAHAM was born in the small town of Lobo, Ontario, Canada, on January $2,1890 .{ }^{1}$ His father, Peter Lamont Graham, was a country physician, whereas his mother, Mary Agnes Reid, stayed home to raise Roscoe and his two brothers. All three of the boys would eventually decide to follow in their father's footsteps and pursue a career in medicine, but it was Roscoe who made the most significant contributions to the world of medicine as a physician surgeon. Although Graham may have been remembered most for his omental patch repair of perforated duodenal ulcers, his career was also highlighted by extensive work regarding the etiology and treatment of rectal prolapse in addition to being the first surgeon to successfully remove an insulinoma.

Graham attended high school at London Collegiate Institute in the nearby town of London, Ontario, Canada, from 1903 to 1906 (Fig. 1). He then went to medical school at the University of Toronto, where he was an

Presented at the John H. Gibbon Grand Rounds and M\&M Department of Surgery, Thomas Jefferson University, Philadelphia, PA, April 4, 2013.

Address correspondence and reprint requests to Scott W. Cowan, M.D., Assistant Professor, Department of Surgery, Thomas Jefferson University, 1025 Walnut Street, Suite 607, Philadelphia, PA 19107. E-mail: scott.cowan@jefferson.edu. active member of $\mathrm{Nu}$ Sigma $\mathrm{Nu}$, the medical fraternity on campus. ${ }^{2}$ Graham received his medical degree in 1910 at the age of 20 years. He worked as an intern at St. Michael's Hospital from 1912 to 1913 under the tutelage of Dr. Gideon Silverthorn. During this time, Roscoe was wed to Beatrice Barry on August 20, 1913, at Niagara Falls. They would go on to have a son, Roscoe Barry, and a daughter, Mary Beatrice.

Following the advice of his mentor, Dr. Silverthorn, Graham pursued a year of postgraduate education abroad. He worked at St. Bartholomew's in London, U.K., and also in the cities of Edinburgh, Vienna, and Berne. During World War I, Graham was recruited by the Royal Canadian Medical Corps to serve as Captain with the No. 4 General Hospital in London, U.K. On his return home, he assumed a position at Toronto General Hospital, where he would spend the rest of his career and eventually become the Head of the First Surgical Division.

The first major success of Graham's surgical career came in January of 1929, when a 54-year-old woman was admitted to Toronto General Hospital with a 6-year history of convulsions and seizure-like activity. A diagnosis of hypoglycemia was suspected after obtaining the patient's history; she reported that eating food, particularly sweets, aborted the convulsive episodes. Graham was consulted by Dr. Goldwin Howland and 


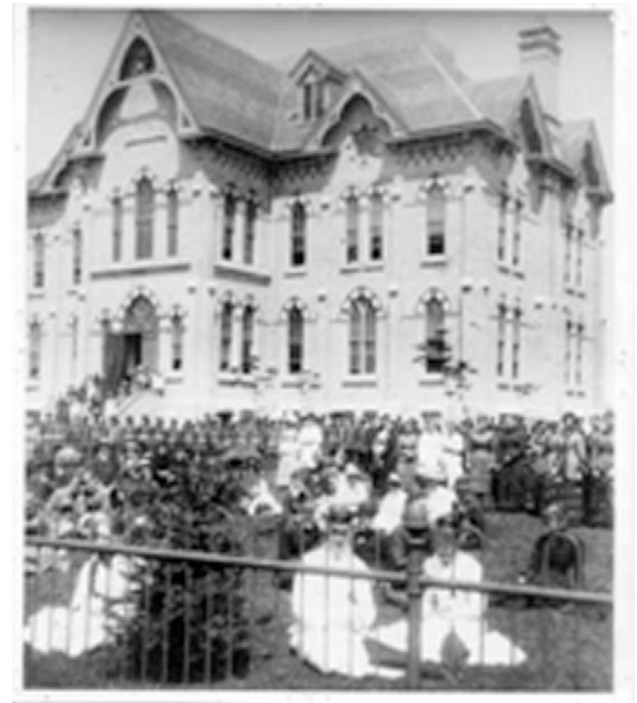

FIG. 1. London Collegiate Institute, where Graham attended high school in London, Ontario, Canada. London Collegiate Institute. London, Ontario, Canada: Ivey Family London Room, London Public Library; 1885.

his assistant, Ray Farquharson, after their attempts at medically managing the problem had failed. They wanted Graham to perform a surgical exploration of the pancreas in the hopes that he would find an insulinoma. Despite the fact that no such surgery had ever been performed, Graham agreed to operate. In fact, insulin itself had only been discovered eight years prior by Graham's colleagues at the University of Toronto, Banting and Best. Indeed, it truly was a time of exploration and discovery.

In his preoperative notes, Graham wondered if he would find any tumor at all. Fortunately, however, he did find a tumor, and he proceeded to enucleate it. The pathology report confirmed the tumor to be an islet cell carcinoma of B-cell origin. The patient recovered well and remained asymptomatic until her death 23 years later. Roscoe Graham thus became the first surgeon to successfully remove an insulinoma. His contributions, however, went largely unrecognized for quite some time. For whatever reason, he neglected to write a case report on this historical patient or contribute to the work of those who did. To this day, he is still remembered more for his work in duodenal ulcers than for this historic surgical accomplishment.

In 1932, at the age of 42 years, Graham became the youngest surgeon ever to be elected as fellow by the American Surgical Association. He had clearly established himself as a leader on the frontier of surgery. With time, his areas of interest began to expand and his expertise flourished. In 1937, his publication in Surgery, Gynecology and Obstetrics, entitled "The Treatment of Perforated Duodenal Ulcers," was well received by his colleagues. Graham wrote a detailed account of his operative approach in addition to providing insight regarding the workup of a patient with a suspected perforated ulcer. He wrote about a "trinity of symptoms" - the association of pain with tenderness, a point of maximal tenderness, and the exacerbation of pain with movement-and how to differentiate a patient with a perforated ulcer from those afflicted with coronary thrombosis or an acute appendix. ${ }^{3}$ The surgical repair described "...could not be more simple: three interrupted catgut sutures are used. One is placed at the top, one in the middle, and one at the bottom of the perforation. A piece of omentum, either free or attached, is laid over these sutures, which are then tied just sufficiently tight to hold the omental graft in situ, but not with sufficient force to cause the sutures to cut out, even in the most edematous indurated ulcer." Furthermore, he wrote on the importance of stabilizing a patient's volume status before surgery and on the benefits of spinal anesthesia. He considered the use of gastroenterotomy a "meddlesome" procedure, stressing that the "...fundamental surgical principle applicable to all emergency surgery-that the patient be treated solely for the lesion creating the emergency-should be observed to a greater degree in the treatment of patients suffering from an acute perforation of a duodenal ulcer than in almost any other acute intraperitoneal lesion." In an age of surgical experimentation, Roscoe's self-restraint in the operating room and unwavering dedication to the needs of the patient brought him welldeserved laudation by many of his colleagues.

In 1939, Graham was nominated Vice President of the American Surgical Association with Allen O. Whipple in the Chair (Fig. 2). He also became the Fellow of both the Royal College of Surgeons of Canada and the American College of Surgeons that year. He served as secretary and later president of the Canadian Association of Clinical Surgeons. In addition to these accolades, he also worked as editor for the Annals of Surgery and authored a chapter, "Surgery of the Abdomen," in Bancroft's textbook. His last major publication, "The Operative Repair of Massive Rectal Prolapse," highlighted Graham's other area of expertise. His conclusion that rectal prolapse is essentially a sliding hernia through the anterior rectal wall was based on the observation that "the lumen (of the rectum) presented on the posterior quadrant of the prolapsed mass" and "...the fact that after reduction of the prolapse, pressure anteriorly by the examining finger in the rectum prevented its recurrence even with straining." 4 His treatment for this defect involved the obliteration of the pouch of Douglas followed by "transabdominal reefing of the levatores." The latter approach, referred to as a levatorplasty, is still used today in more complicated patients. Graham's contributions 


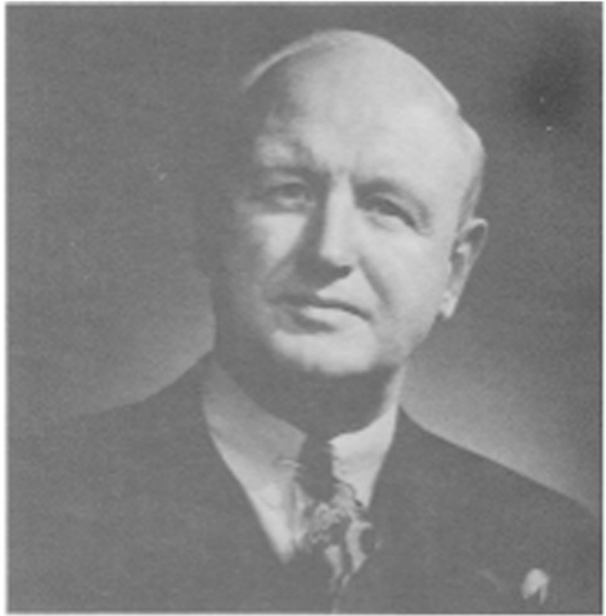

\section{Roncoe Reid Graham}

[Photograph courtess of Miss Kathr Graham.]

FIG. 2. Professional portrait of Roscoe Reid Graham. Graham RR. Portrait photograph, courtesy of Miss Kathy Graham. Taken from Classic Articles in Rectal and Colonic Surgery 1985;28:374-9.

to the field of surgery were vast; his techniques are still revered by many surgeons throughout the world.

At the young age of 58 years, while skiing in Canada, Roscoe Reid Graham died suddenly from acute coronary thrombosis, a condition whose symptoms he described in his 1937 publication on the treatment of perforated ulcers. Although his death was certainly a premature one, the legacy he left behind has lived on in his absence (Fig. 3). The natural diagnostic intuition he had with his patients, combined with his utter dedication to their betterment, made him a simply outstanding physician. In an age when medical professionals can often be too "meddlesome," it is imperative that we look back at our predecessors such as Roscoe Reid Graham, for they will continually

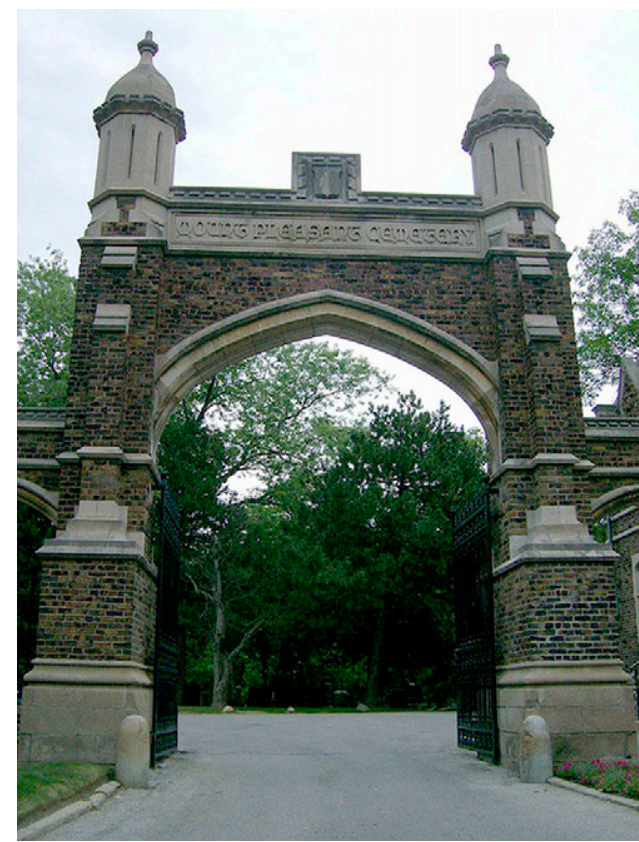

FIG. 3. Mount Pleasant Cemetery in Toronto, Ontario, Canada, where Dr. Graham is buried. Mount Pleasant Cemetery in Toronto. Ontario, Canada, where Dr. Graham was laid to rest. Available at: www.findagrave.com/cgi-bin/fg.cgi?page=gr@ GRid=79235800. Accessed March 14, 2013.

redirect us toward our one and only obligation: the patient.

\section{REFERENCES}

1. De La Fuente SG, Pappas TN. Roscoe Reid Graham (18901948): the man of the patch. Curr Surg 2002;49:428-9.

2. Thompson LO, Downs WS. . Who's Who in American Medicine. New York, NY: Who's Who Publications, Inc.; 1925.

3. Graham RR. The treatment of perforated duodenal ulcers. Surg Gynecol Obstet 1937;64:235-8.

4. Graham RR. The operative repair of massive rectal prolapse. Ann Surg 1942;715:1007-14. 